\title{
Productivity feedback did not terminate the Paleocene-Eocene Thermal Maximum (PETM)
}

\author{
A. Torfstein ${ }^{1}$, G. Winckler ${ }^{1,2}$, and A. Tripati ${ }^{3, *}$ \\ ${ }^{1}$ Lamont-Doherty Earth Observatory, Columbia University, 61 Rt. 9W, Palisades, NY 10964-1000, USA \\ ${ }^{2}$ Department of Earth and Environmental Sciences, Columbia University, NY 10027, USA \\ ${ }^{3}$ Department of Earth Sciences, University of Cambridge, Downing Street, Cambridge, CB2 3EQ, UK \\ * now at: Department of Earth and Space Sciences and Institute of Geophysics and Planetary Physics, University of \\ California, Los Angeles, 595 Charles Young Drive East, Los Angeles, CA 90095-1567, USA
}

Received: 11 September 2009 - Published in Clim. Past Discuss.: 27 October 2009

Revised: 14 March 2010 - Accepted: 1 April 2010 - Published: 16 April 2010

\begin{abstract}
The Paleocene-Eocene Thermal Maximum (PETM) occurred approximately 55 million years ago, and is one of the most dramatic abrupt global warming events in the geological record. This warming was triggered by the sudden release of thousands of gigatons of carbon into the atmosphere and is widely perceived to be the best analogue for current anthropogenic climate change. Yet, the mechanism of recovery from this event remains controversial. A massive increase in the intensity of the marine biological pump ("productivity feedback") has been suggested to cause a drawdown of atmospheric $\mathrm{CO}_{2}$ and subsequent carbon sequestration in the ocean. A re-evaluation of the "productivity feedback hypothesis", based on biogenic barium mass accumulation rates (Ba-MARs) for a site in the Southern Ocean, finds that any increase in export production lagged the initial carbon release by at least $\sim 70000$ years. This implies that export production did not facilitate rapid removal of excess carbon from the atmosphere. Thus, the most likely mechanism for carbon removal appears to be silicate weathering, which occurred at much slower rates than previously assumed.
\end{abstract}

\section{Introduction}

Carbon and oxygen isotope records indicate that the PETM occurred in response to the release of several thousand gigatons of carbon into the atmosphere, presenting a test case in the geological record of the Earth's climate response to rapid

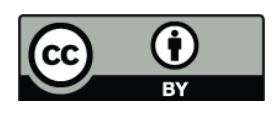

Correspondence to: A. Torfstein (adi.torf@ldeo.columbia.edu) anthropogenic warming (Dickens et al., 1995; Thomas and Shackleton, 1996; Zachos et al., 2001; Higgins and Schrag, 2006; Pagani et al., 2006). Sea surface temperatures (SSTs) are estimated to have risen by $5{ }^{\circ} \mathrm{C}$ in the tropics and by up to $9^{\circ} \mathrm{C}$ at high latitudes (Kennett and Stott, 1991; Zachos et al., 2003) with peak polar temperatures in excess of $20^{\circ} \mathrm{C}$ (Sluijs et al., 2006). Environmental changes resulted in the extinction of $30-50 \%$ of deep-sea benthic foraminiferal species (Thomas and Shackleton, 1996) as well as the dispersal of land mammals (Bowen et al., 2002).

The source and mass of carbon released at the PETM are not well understood, in part due to the limited number of existing records of deep-water carbon chemistry. Constraints on the source and mass of carbon come from the measured magnitude of the $\delta^{13} \mathrm{C}$ anomaly (typically $\sim 2-3 \%$, but possibly up to $6 \%$ (Schouten et al., 2007); referred to here as the carbon isotope excursion, CIE) and the shoaling of the carbonate compensation depth (CCD) (Kennett and Stott, 1991; Dickens et al., 1997; Zachos et al., 2001, 2005; Pagani et al., 2006). The trigger for the carbon emission is controversial, with several suggested mechanisms, e.g., gradual global warming (Zachos et al., 2001; Sluijs et al., 2007), intrusive volcanism (Bralower et al., 1997; Svensen et al., 2004), a bolide impact (Kent et al., 2003), an abrupt change in ocean circulation (Dickens et al., 1995; Thomas and Shackleton, 1996; Bice and Marotzke, 2002; Tripati and Elderfield, 2004, 2005; Nunes and Norris, 2006), or massive submarine landslides (Katz et al., 1999).

Equally ambiguous is the mechanism and rate by which this excess carbon was removed from the atmosphere and oceans. One of the most prominent hypotheses in this regard is that a sharp increase in marine biological productivity and an associated increase in export production resulted in a

Published by Copernicus Publications on behalf of the European Geosciences Union. 


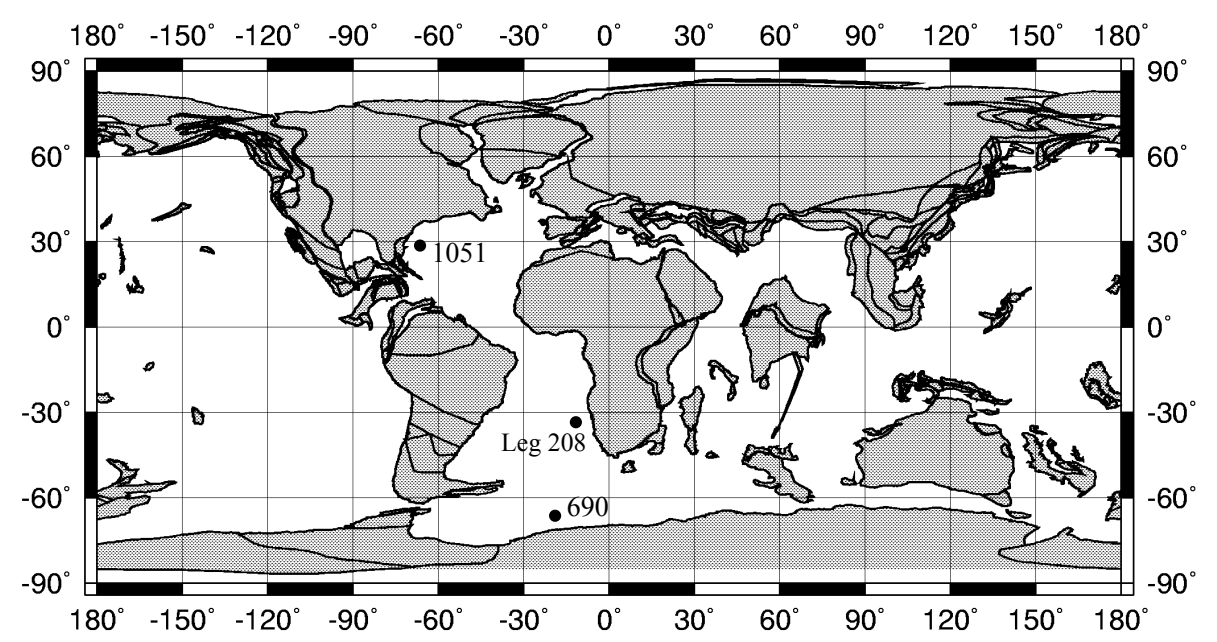

Fig. 1. Paleogeographic reconstruction of late Paleocene (Hay et al., 1999) and sites discussed in this paper.

drawdown of atmospheric $\mathrm{CO}_{2}$ concentrations. This 'productivity feedback hypothesis' is based on a pronounced increase in the mass accumulation rates of biogenic barium, a proxy of export production in surface waters, at ODP sites 690 and 1051 (Figs. 1, 2) (Bains et al., 2000), with similar observations elsewhere (Schmitz et al., 1997; Faul and Paytan, 2005; Paytan and Griffith, 2007). While high primary productivity during the PETM is supported by some reconstructions of oceanic productivity (Thomas and Shackleton, 1996; Crouch et al., 2001; Bains et al., 2003; Stoll and Bains, 2003; Stoll et al., 2007), other studies are either ambiguous or at odds with this conclusion (Bralower, 2002; Bowen et al., 2004; Kelly et al., 2005; Paytan et al., 2007), yielding conflicting results and differing interpretations.

Here, we test the "productivity feedback hypothesis" (Bains et al., 2000) by re-evaluating the productivity record at Site 690, which is located in the Southern Ocean (Fig. 1), and is the most complete and well studied PETM record to date.

\section{Methodology}

Marine barite and biogenic barium (the fraction of $\mathrm{Ba}$ in marine sediments that is not of terrigenous origin) correspond to the organic carbon flux from the surface ocean to the deep ocean (export production). Their preservation (in non-sulfate reducing environments) is high and their mass accumulation rates in the sedimentary record are thus considered robust proxies for past export production (Goldberg and Arrhenius, 1958; Bishop, 1988; Legeleux and Reyss, 1996; Paytan et al., 1996; Monnin et al., 1999; Paytan and Griffith, 2007).

Ba-MARs reflect the measured element concentrations (i.e. [Ba]) and the bulk mass accumulation rates (bulkMARs). The latter are themselves a function of sediment dry bulk density $(\rho)$ and the linear sedimentation rates (LSR) (Eq. 1).

$\mathrm{BaMAR}=$ bulkMAR $\cdot[\mathrm{Ba}]=\mathrm{LSR} \cdot \rho \cdot[\mathrm{Ba}]$,

LSR are obtained from independent age constraints such as orbital-tuning, magnetostratigraphy or absolute dating methods, rendering the bulk- and Ba- MARs sensitive to the choice of age model (Curry and Lohmann, 1986; Lyle et al., 1988; Rea and Leinen, 1988; Francois et al., 2004; Lyle et al., 2005). Thus, any interpretation of Ba-MARs in the context of the PETM event will depend on the validity of the underlying age model. The original age model used to calculate the discussed Ba-MARs was initially established for ODP site 1051 by orbital-tuning (Norris and Röhl, 1999) and later expanded to ODP Site 690 by correlating $\delta^{13} \mathrm{C}$ peaks (Bains et al., 2000). Several refined high-resolution age models have subsequently been established for this site (Röhl et al., 2000; Farley and Eltgroth, 2003; Röhl et al., 2007; a detailed review and comparison between these models was provided by Sluijs et al., 2007). Here, we re-examine the export production record during the PETM, reconstructed from Ba-MARs, by using two independent updated age models (Fig. 3).

\section{$2.1 \quad{ }^{3} \mathrm{He}-$ based approach}

The first re-evaluation expands on the study of Farley and Eltgroth (2003) who produced a highly resolved ${ }^{3} \mathrm{He}$ record for ODP site $690 .{ }^{3} \mathrm{He}$ in sediments primarily derived from small interplanetary dust particles (IDPs) (Farley et al., 1997; Farley, 2001). Because the helium isotopic composition of the interplanetary dust signal differs from terrestrial material by four orders of magnitude, isotopic measurements can be used to identify the extraterrestrial source and quantify its fraction in the sediment. Assuming that the flux of extraterrestrial ${ }^{3} \mathrm{He}$ to the Earth's surface $\left(\mathrm{F}_{3 \mathrm{He}}\right)$ is constant over a certain time period (Marcantonio et al., 1996, 


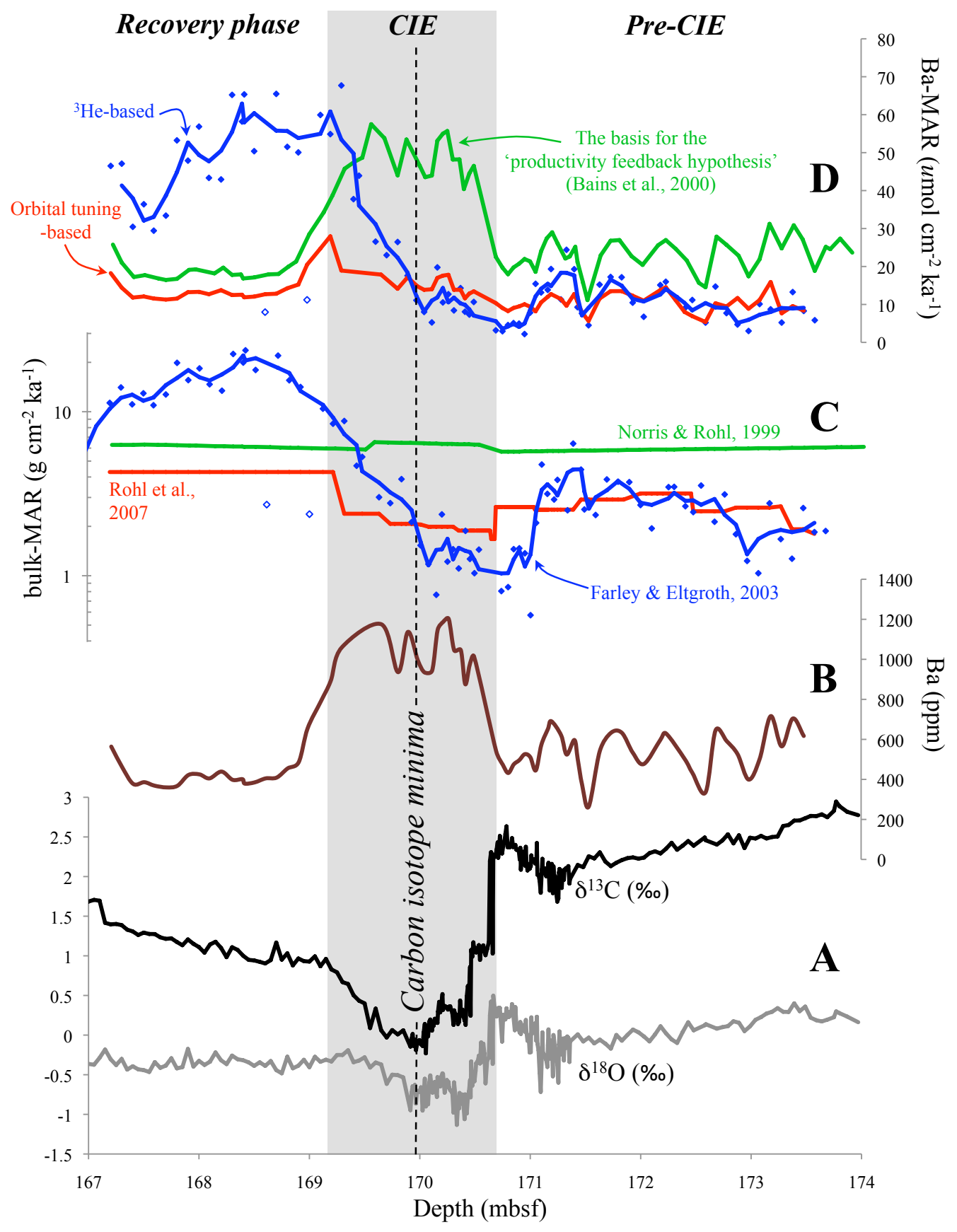

Fig. 2. (A) Bulk $\delta^{13} \mathrm{C}$ and $\delta^{18} \mathrm{O}$ values during the PETM interval vs. depth (meters below seafloor, mbsf) at ODP site 690 (Bains et al., 1999). The shadowed area represents the duration of the carbon isotope excursion (CIE) stage. (B) Ba concentrations (Bains et al., 2000). (C) Sediment bulk mass accumulation rates (bulk-MARs) according to the three age models: the original orbitally-tuned age model of Norris and Röhl (1999) (green), the refined orbitally-tuned age model of Röhl et al. (2007) (red) and the ${ }^{3}$ He-derived age model (Farley and Eltgroth, 2003) (blue; the blue curve represent a 3-point running average excluding the two open symbols as outliers, Farley and Eltgroth, 2003). The Norris and Röhl (1999) age model pertains to ODP site 1051 and was interpolated by Bains et al. (2000) to ODP site 690. (D) Barium mass accumulation rates (Ba-MARs) calculated according to three age models. Colors and symbols correspond to (B). Note the marked difference in the timing of Ba-MARs peaks obtained using the sedimentation rates of Farley and Eltgroth (2003) and Röhl et al. (2007) compared to those of Bains et al. (1999). The shadowed area represents the duration of the carbon isotope excursion (CIE) stage. The dashed line in the center of the CIE marks the carbon isotope minima (CIM) and coincides the initial increase of bulk- and Ba- MAR, marking the start of the recovery phase. We note that Farley and Eltgroth (2003) used the timing of adjacent magnetochrons (24R and 25R) to calculate the apparent ${ }^{3} \mathrm{He}$ flux at site 690. A recent update of the timing of these magnetochrons (Westerhold et al., 2007) dictates a minor propagated change in the ${ }^{3} \mathrm{He}$-derived chronology. For consistency with published data, and because the changes in the updated chronology are small and do not affect any of the conclusions of our study, we refer to the original age model of (Farley and Eltgroth, 2003). 


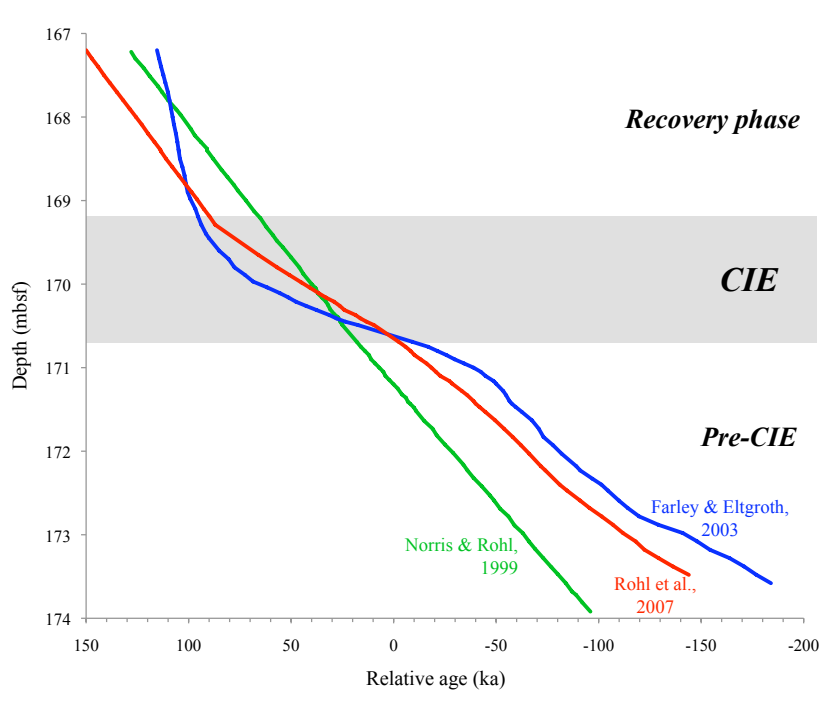

Fig. 3. Relative age (ka) vs. depth (mbsf) according to to the three age models discussed in the paper.

1999; Mukhopadhyay et al., 2001; Farley and Eltgroth, 2003; Winckler et al., 2004, 2005) and can be determined, for example by measuring the amount of extraterrestrial ${ }^{3} \mathrm{He}$ over a well known, independently dated adjacent time interval, ${ }^{3} \mathrm{He}$ concentration measurements can be inverted to calculate bulk-MARs (Eq. 2).

bulkMAR $=\frac{F_{3} \mathrm{He}}{{ }^{3} \mathrm{He}}$,

One of the advantages of this approach is that it provides instantaneous mass accumulation rates at each sample depth, whereas the resolution of orbital-tuning is limited to about $\sim 20 \mathrm{ka}$ (precession cycle). Farley and Eltgroth (2003) used this constant flux proxy approach to reconstruct bulk-MARs for the PETM interval at ODP sites 690 and 1051 (Fig. 1). The record at the latter site is disrupted and we thus focus our discussion on the former site.

\subsection{Orbitally-tuned age models}

The second and more common approach used to determine the chronological framework of the PETM is orbital-tuning (Norris and Röhl, 1999; Röhl et al., 2000), whereby repeated cycles of elemental concentrations or lithological components are assumed to represent precession cycles $(\sim 20 \mathrm{ka})$, and thus, the time-length of particular sequences within a sedimentary section can be determined. Here, we focus on the most recent orbitally-tuned age model by Röhl et al. (2007) which is based on a wide compilation of data from several sites as well as an adjacent age calibration for the Paleocene-Eocene transition (Westerhold et al., 2007, 2008). This age model presents a refinement of the age-model (Norris and Röhl, 1999) used by Bains et al. (2000).

\section{Reconstructions of mass accumulation rates}

In the following discussion we re-evaluate the bulk- and BaMARs based on the two age models detailed above for ODP site 690 in the Southern Ocean. The ${ }^{3} \mathrm{He}$-derived age model suggests a slight decrease in bulk-MARs shortly before the CIE (Fig. 2). Approximately $70 \mathrm{ka}$ after the start of the CIE, bulk-MARs started a gradual increase and reached a maximum rate of $\sim 20-25 \mathrm{~g} /\left(\mathrm{cm}^{2} \mathrm{ka}\right.$ ) (an order of magnitude increase) about $\sim 20$ ka later. The bulk-MAR record based on the updated orbitally-tuned age model (Röhl et al., 2007) is in reasonable agreement with the ${ }^{3} \mathrm{He}$-derived age model for the time period before and during most of the CIE (Fig. 2).

However, the two age models display significant divergence starting at $\sim 169.8 \mathrm{~m}$, coincident with the carbon isotope minima (CIM) point. While the ${ }^{3} \mathrm{He}$-derived age model implies the start of a gradual but significant increase in bulkMAR from this point onwards, the orbitally-tuned age model implies relative constant bulk-MARs until the end of the CIE, after which it increases abruptly and remains constant thereafter.

A potential cause for this difference between the age models is massive carbonate dissolution, reflecting the temporal shoaling of the CCD during the PETM (Zachos et al., 2005). Such dissolution condenses sedimentary sections and could bias the interpreted bulk-MARs towards lower values. It is also likely to have a larger impact on the orbitally-tuned age models compared to the ${ }^{3} \mathrm{He}$-derived ages because the former would be "missing" cycles, while the latter would still record the accumulated ${ }^{3} \mathrm{He}$ signal in the primarily insoluble IDP particles. Under such conditions, the actual bulk-MARs should be higher, closer to those suggested by Farley and Eltgroth (2003). Indeed, the significant environmental changes associated with the PETM would most likely have affected non-carbonate sedimentation, also influencing MARs. This is further supported by shifts in the lithology of the PETM sequence at Site 690 and elsewhere (e.g. Walvis Ridge, Shatsky Rise) (Zachos et al., 2003, 2005). Lacking any absolute standard to evaluate the age models against, the large perturbation expressed by the ${ }^{3} \mathrm{He}$-derived age model seems to better reflect such a scenario, compared to the relatively constant deposition rates implied by the orbitally-tuned age models (Fig. 3).

\section{Barium MARs and discrepancies regarding biosphere feedback}

Despite the differences between them, both re-evaluations are internally consistent and indicate relatively constant BaMARs during the first $\sim 70 \mathrm{ka}$ of the CIE, as recorded in the Southern Ocean, in sharp contrast to the original interpretation of Bains et al. (2000) (Fig. 4). Differences in Ba-MARs develop after the CIM, corresponding to the transition to the recovery phase (Fig. 2). Thereafter, Ba-MARs either display 
an abrupt six to seven -fold increase, as predicted by the ${ }^{3}$ He-based age model (Farley and Eltgroth, 2003), or remain overall constant, as implied by the orbitally-tuned age model (Röhl et al., 2007). Given the fact that the bulk-MARs is a function of $\rho$ and LSR (Eq. 1), and that the $\rho$ remains overall similar throughout the sedimentary sequence, any changes in Ba-MARs must reflect corresponding patterns in the LSR or in the barium concentrations. Thus, according to orbital tuning a small peak of Ba-MARs at $\sim 169.2 \mathrm{~m}$ ( $\sim 90 \mathrm{ka}$ after start of CIE), represents a short overlap between a sequence of increased Ba concentrations to the rise in LSR. It is not clear whether this small peak is real or if it is the result of a small offset in one of the above (i.e. LSR or [Ba]). Regardless, its magnitude and length of time are such that the implied shift in Ba-MARs is negligible.

Evidently, the coincidence between increased Ba concentrations and the CIE (Fig. 2a) does not reflect higher productivity or a change in the marine cycle of $\mathrm{Ba}$ as previously thought, but rather, the condensation of the sedimentary section due to ocean acidification and carbonate dissolution. Contrary to the "productivity feedback hypothesis" (Bains et al., 2000), there appears to have been no notable change in marine export production until at least $\sim 70 \mathrm{ka}$ after the onset of the CIE (Fig. 4).

This finding is based on results from ODP site 690 in the Southern Ocean, which is a key site in the PETM research, and one that has long been considered to contain the "typesection" for this event. Indeed, the majority of previous investigations of PETM records in the open ocean have focused on relatively few sites (e.g. ODP site 1051, ODP leg 208 and others, but most notably ODP site 690). In this regards, it would be desirable to confirm the interpretation and age models discussed in this work in additional locations, especially those representing open ocean environments. Although the ${ }^{3} \mathrm{He}$-based age model is currently available only at ODP site 690 (along with a partial record at ODP site 1051; Farley and Eltgroth, 2003), it appears reasonable to assume that its patterns and implications, as presented in this paper, are in general representative of the open ocean environment.

Our results shed new light on the ongoing debate over the response of the marine biosphere to carbon release at the PETM, and resolve some discrepancies between different studies. While some calcareous nannofossil assemblages, were interpreted to record oligotrophic conditions in the open oceans during the PETM (Bolle et al., 2000; Bralower, 2002; Bowen et al., 2004; Kelly et al., 2005), other studies argued for a rise in primary productivity in surface waters, supporting the biological pump as a major negative feedback to the greenhouse warming (Schmitz et al., 1997; Crouch et al., 2001; Stoll and Bains, 2003; Stoll et al., 2007). Yet these lines of evidence are ambiguous. For example, increased productivity during the CIE was suggested on the basis of a limited increase of $\mathrm{Sr} / \mathrm{Ca}$ ratios in some (but not all) calcareous nannofossil assemblages (Stoll and Bains, 2003; Stoll et al., 2007). Additional complications arise from the magni-

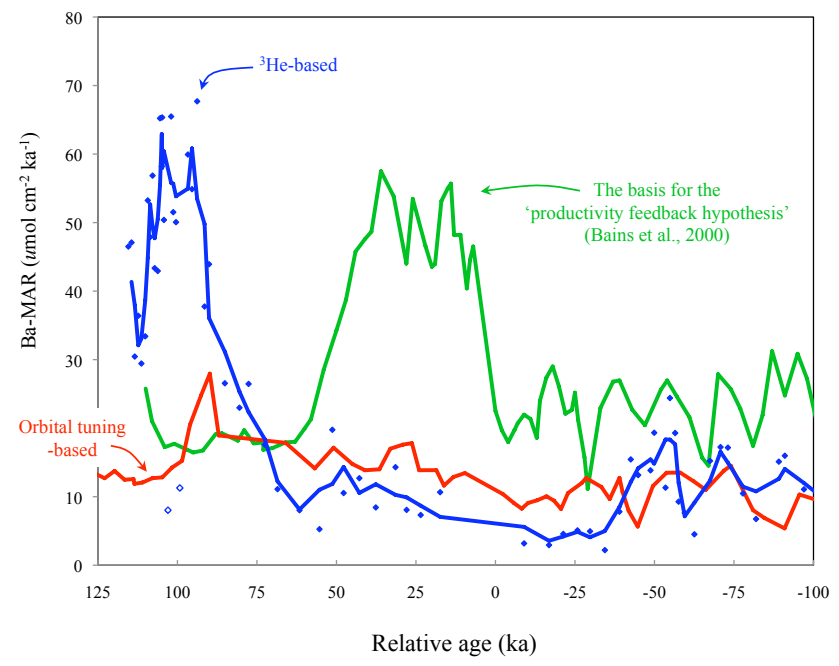

Fig. 4. Ba-MARs vs.age relative to the onset of the carbon isotope excursion (CIE). Both the ${ }^{3} \mathrm{He}$-based and the refined orbitallytuned records indicate relatively constant export production during the first $\sim 70 \mathrm{ka}$ of the CIE, in sharp contrast to the original interpretation by Bains et al. (2000). Thereafter the two new records diverge: while the ${ }^{3} \mathrm{He}$-based Ba-MARs display a gradual increase and reach a maximum about $\sim 20 \mathrm{ka}$ later, the refined orbitallytuned age model implies relatively constant Ba-MARs throughout the entire event. Colors pertain to the legend of Fig. 2.

tude of change in Ba-MARs relative to the short duration of the PETM event, which present mass balance problems. A possible explanation for this discrepancy is the influx of an external source of $\mathrm{Ba}$ to the oceans (Dickens et al., 2003) or alternatively, a mechanism of spatial differential deposition of barite whereby the excess Ba-MARs are counterbalanced by limited Ba-MARs in other unidentified sites (Dickens et al., 2003; Paytan et al., 2007). The latter suggestion is supported by constant marine $\mathrm{Sr} / \mathrm{Ba}$ ratios observed throughout the PETM implying no change in barite saturation in the oceans despite the changes in Ba-MARs (Paytan et al., 2007). Clearly, the revised Ba-MARs records presented here warrant re-consideration of some of the ideas detailed above.

The revised Ba-MARs imply that any significant change in export production in the Southern Ocean lagged the abrupt rise in $\mathrm{CO}_{2}$ by at least $\sim 70 \mathrm{ka}$, or did not take place at all. In the case of the ${ }^{3} \mathrm{He}$-derived model, this increase in Ba-MARs is synchronous with the CIM, when bulk $\delta^{13} \mathrm{C}$ values shift from a continuous trend of depletion in ${ }^{13} \mathrm{C}$, back towards heavier, pre-CIE values, marking the start of a period of recovery back to pre-PETM conditions (indicated in Fig. 2 by the dashed black curve). This transition is also synchronous with evidence for a bloom of species of planktic foraminifera (Acarinina subsphaerica) (Kelly et al., 2005) and a rise in the kaolinite abundances (Robert and Kennett, 1994). Combined, these lines of evidence indicate that the mechanism responsible for $\mathrm{CO}_{2}$ drawdown and carbonate precipitation 
in the oceans "kick-started" abruptly about $\sim 70 \mathrm{ka}$ after the initial CIE. Yet, the nature of this triggering mechanism remains unclear.

\section{Conclusions and implications}

The natural mechanisms of recovery from the PETM are of fundamental interest in the context of present day global warming. Nevertheless, these mechanisms are not well constrained and are still under debate. A central observation in this context is a prominent increase in biogenic barium mass accumulation rates (Ba-MARs) observed within the PETM sequence at ODP site 690 in the Southern Ocean. The increase in Ba-MARs is thought to be a proxy for increased export production in surface waters and hence, has been argued to indicate that a massive biogeochemical productivity feedback in the ocean was the main mechanism that supported $\mathrm{CO}_{2}$ draw down and recovery from the PETM (Bains et al., 2000). The Ba-MARs record however, is sensitive to the chronological framework established for the sedimentary sequence. In this paper we re-evaluated the Ba-MARs at ODP site 690 based on the updated age models of Farley and Eltgroth (2003) and Röhl et al. (2007).

Our re-evaluation of the "productivity feedback hypothesis" at ODP site 690 across the PETM interval reveals the sensitivity of the interpretation of the BaMAR record to the choice of the chronological framework established for the sedimentary sequence. The pronounced peak of the BaMARs during the main stage of the PETM, which served as the observational evidence for the original hypothesis (Bains et al., 2000) is an artifact of the initial age model. Reevaluation of the sedimentary record using the original barium data and updated age models indicates that export production in the Southern Ocean was either constant throughout the event, or lagged the abrupt rise in $\mathrm{CO}_{2}$ by at least $\sim 70 \mathrm{ka}$, in sharp contrast to previous results. This implies that export production did not rapidly remove excess carbon from the atmosphere, and renders the most likely mechanism for carbon removal to be silicate weathering, at much slower rates than previously assumed. It is intriguing that the carbon isotope minimum, marking the peak of the PETM, is promptly followed by a rise in kaolinite abundances (Robert and Kennett, 1994) and a bloom of species of planktic foraminifera (Acarinina subsphaerica) (Kelly et al., 2005), suggesting that the recovery phase was triggered by a discrete event that "kick-started" abruptly about $\sim 70$ $\mathrm{ka}$ after the initial CIE. The nature of this trigger is unclear but we speculate, in accord with previous studies (Bice and Marotzke, 2002; Tripati and Elderfield, 2004, 2005; Nunes and Norris, 2006), that it involves a change in the global ocean setting and the resumption of deep-water formation in the Southern Ocean.
Accepting the PETM event as an analogue for current global warming, the primary natural path of carbon sequestration in response to $\mathrm{CO}_{2}$ spiking does not appear to involve oceanic biogeochemical feedbacks, implying that efforts to enhance these processes (e.g. the "iron hypothesis", Martin, 1992) might not be quantitatively sufficient; additional paths should therefore be considered in the context of present day warming and the search for means to reduce atmospheric carbon content.

Acknowledgements. We would like to thank S. Bains and R. Norris for providing published data from Site 690. A. Tripati was supported by NERC and Magdalene College. W. Broecker and Y. Kolodny provided valuable comments to an earlier version of this manuscript. We thank A. Sluijs and an anonymous reviewer for constructive remarks that helped improve this paper significantly.

Edited by: G. M. Ganssen

\section{References}

Bains, S., Corfield, R. M., Norris, and R. D.: Mechanisms of climate warming at the end of the Paleocene, Science, 285, 724727, 1999.

Bains, S., Norris, R. D., Corfield, R. M., and Faul, K. L.: Termination of global warmth at the Palaeocene/Eocene boundary through productivity feedback, Nature, 407, 171-174, 2000.

Bains, S., Norris, R. D., Corfield, R. M., Bowen, G. J., Gingerich, P. D., and Koch, P. L.: Marine-terrestrial linkages at the PaleoceneEocene boundary, Geol. S. Am. S., 369, 1-9, 2003.

Bice, K. L. and Marotzke, J.: Could changing ocean circulation have destabilized methane hydrate at the $\mathrm{Pa}$ leocene/Eocene boundary, Paleoceanography, 17(2), doi:10.1029/2001PA000678, 2002.

Bishop, J. K. B.: The barite-opal-organic carbon association in oceanic particulate matter, Nature, 332, 341-343, 1988.

Bolle, M. P., Pardo, A., Adatte, T., Von Salis, K., and Burns, S.: Climatic evolution on the southeastern margin of the Tethys (Negev, Israel) from the Palaeocene to the early Eocene: focus on the late Palaeocene thermal maximum, J. Geol. Soc. London, 157, 929-941, 2000.

Bowen, G. J., Clyde, W. C., Koch, P. L., Ting, S., Alroy, J., Tsubamoto, T., Wang, Y., and Wang, Y.: Mammalian Dispersal at the Paleocene/Eocene Boundary, Science, 295, 2062-2065, 2002.

Bowen, G. J., Beerling, D. J., Koch, P. L., Zachos, J. C., and Quattlebaum, T.: A humid climate state during the Palaeocene/Eocene thermal maximum, Nature, 432, 495-499, 2004.

Bralower, T. J., Thomas, D. J., Zachos, J. C., Hirschmann, M. M., Röhl, U., Sigurdsson, H., Thomas, E., and Whitney, D. L.: Highresolution records of the late Paleocene thermal maximum and circum-Caribbean volcanism: Is there a causal link?, Geology, 25, 963-966, 1997.

Bralower, T. J.: Evidence of surface water oligotrophy during the Paleocene-Eocene thermal maximum: Nannofossil assemblage data from Ocean Drilling Program Site 690, Maud Rise, Weddell Sea, Paleoceanography, 17, 1023, doi:1010.1029/2001PA000662., 2002. 
Crouch, E. M., Heilmann-Clausen, C., Brinkhuis, H., Morgans, H. E. G., Rogers, K. M., Egger, H., and Schmitz, B.: Global dinoflagellate event associated with the late Paleocene thermal maximum, Geology, 29, 315-318, 2001.

Curry, W. B. and Lohmann, G. P.: Late Quaternary carbonate sedimentation at the Sierra Leone Rise (eastern equatorial Atlantic Ocean), Mar. Geol., 70, 223-250, 1986.

Dickens, G. R., Castillo, M. M., and Walker, J. C. G.: A blast of gas in the latest Paleocene: Simulating first-order effects of massive dissociation of oceanic methane hydrate, Geology, 25, 259-262, 1997.

Dickens, G. R., Fewless, T., Thomas, E., and Bralower, T. J.: Excess barite accumulation during the Paleocene-Eocene Thermal Maximum: Massive input of dissolved barium from seafloor gas hydrate reservoirs, edited by: Wing, S. L., Gingerich, P. D., Schmitz, B., and Thomas, E., Causes and Consequences of Globally Warm Climates in the Early Paleogene: Boulder, Colorado, Geological Society of America Special Paper 369, 11-23, 2003.

Dickens, G. R., O'niel, J. R., Rea, D. K., and Owen, R. M.: Dissociation of oceanic methane hydrate as a cause of carbon isotope excursion at the end of the Paleocene, Paleoceanography, 10, 965-971, 1995.

Farley, K. A., Love, S. G., and Patterson, D. B.: Atmospheric entry heating and helium retentivity of interplanetary dust particles, Geochim. Cosmochim. Ac., 61, 2309-2316, 1997.

Farley, K. A.: Extraterrestrial helium in seafloor sediments: identification, characteristics, and accretion rate over geologic time, in: Accretion of Extraterrestrial matter throughout Earth's History, edited by: Peucker-Ehrenbrink, B. and Schmitz, B., Kluwer Academic/Plenum Publishers, New York, 179-204, 2001.

Farley, K. A. and Eltgroth, S. F.: An alternative age model for the Paleocene-Eocene thermal maximum using extraterrestrial $\mathrm{He}-3$, Earth Planet. Sc. Lett., 208, 135-148, 2003.

Faul, K. L. and Paytan, A.: Phosphorus and barite concentrations and geochemistry in Site 1221 Paleocene/Eocene boundary sediments, in: Proceedings of the Ocean Drilling Program, Scientific Results, Vol. 199. edited by: Wilson, P. A., Lyle, M., and Firth, J. V., 2005.

Francois, R., Frank, M., van der Loeff, M. M. R., and Bacon, M. P.: 230 Th normalization: An essential tool for interpreting sedimentary fluxes during the late Quaternary, Paleoceanography, 19, PA1018, doi:1010.1029/2003PA000939, 2004.

Goldberg, E. D. and Arrhenius, G. O. S.: Chemistry of Pacific pelagic sediments, Geochim. Cosmochim. Ac., 13, 153-212, 1958.

Hay, W. W., DeConto, R., Wold, C. N., Wilson, K. M., Voigt, S., Schulz, M., Wold-Rossby, A., Dullo, W.-C., Ronov, A. B., Balukhovsky, A. N., and Soeding, E.: Alternative global Cretaceous paleogeography, in: The Evolution of Cretaceous Ocean/Climate Systems, edited by: Barrera, E. and Johnson, C., Geol. S. Am. S., 1-47, 1999.

Higgins, J. A. and Schrag, D. P.: Beyond methane: towards a theory for the Paleocene-Eocene thermal maximum, Earth Planet. Sc. Lett., 245, 523-537, 2006.

Katz, M. E., Pak, D. K., Dickens, G. R., and Miller, K. G.: The source and fate of massive carbon input during the latest Paleocene thermal maximum, Science, 286, 1531-1533, 1999.

Kelly, D. C., Zachos, J. C., Bralower, T. J., and Schellenberg, S. A.: Enhanced terrestrial weathering/runoff and surface ocean car- bonate production during the recovery stages of the PaleoceneEocene thermal maximum, Paleoceanography, 20, PA4023, doi:10.1029/2005PA001163, 2005.

Kennett, J. P. and Stott, L. D.: Abrupt deep-sea warming, palaeoceanographic changes and benthic extinctions at the end of the Paleocene, Nature, 353, 225-229, 1991.

Kent, D. V., Cramer, B. S., Lanci, L., Wang, D., Wright, J. D., and Van der Voo, R.: A case for a comet impact trigger for the Paleocene/Eocene thermal maximum and carbon isotope excursion, Earth Planet. Sc. Lett., 211, 13-26, 2003.

Legeleux, F. and Reyss, J. L.: Ra-228/Ra-226 activity ratio in oceanic settling particles: Implications regarding the use of barium as a proxy for paleoproductivity reconstruction, Deep-Sea Res. Pt. I, 43, 1857-1863, 1996.

Lourens, L. J., Sluijs, A., Kroon, D., Zachos, J. C., Thomas, E., Röhl, U., Bowles, J., and Raffi, I.: Astronomical pacing of late Palaeocene to early Eocene global warming events, Nature, 435, 1083-1087, 2005.

Lyle, M., Murray, D. W., Finney, B. P., Dymond, J., Robbins, J. M., and Brooksforce, K.: The record of late Pleistocene biogenic sedimentation in the eastern tropical Pacific Ocean, Paleoceanography, 3, 39-59, 1988.

Lyle, M., Mitchell, N., Pisias, N., Mix, A., Martinez, J. I., and Paytan, A.: Do geochemical estimates of sediment focusing pass the sediment test in the equatorial Pacific, Paleoceanography, 20, 112,2005

Marcantonio, F., Anderson, R. F., Stute, M., Kumar, N., Schlosser, P., and Mix, A.: Extraterrestrial $\mathrm{He}-3$ as a tracer of marine sediment transport and accumulation, Nature, 383, 705-707, 1996.

Marcantonio, F., Turekian, K. K., Higgins, S., Anderson, R. F., Stute, M., and Schlosser, P.: The accretion rate of extraterrestrial He-3 based on oceanic Th-230 flux and the relation to Os isotope variation over the past 200,000 years in an Indian Ocean core, Earth Planet. Sc. Lett., 170, 157-168, 1999.

Martin, J. H.: Glacial-interglacial CO2 change: The iron hypothesis, Paleoceanography, 5, 1-13, 1992.

Monnin, C., Jeandel, C., Cattaldo, T., and Dehairs, F.: The marine barite saturation state of the world's oceans, Marine Chemistry, 65, 253-261, 1999.

Mukhopadhyay, S., Farley, K. A., and Montanari, A.: A short duration of the Cretaceous-Tertiary boundary event: Evidence from extraterrestrial helium-3, Science, 291, 1952-1955, 2001.

Nicolo, M. J., Dickens, G. R., Hollis, C. J., and Zachos, J. C.: Multiple early Eocene hyperthermals: Their sedimentary expression on the New Zealand continental margin and in the deep sea, Geology, 35, 699-702, 2007.

Norris, R. D. and Röhl, U.: Carbon cycling and chronology of climate warming during the Palaeocene/Eocene transition, Nature, 401, 775-778, 1999.

Nunes, F. and Norris, R. D.: Abrupt reversal in ocean overturning during the Palaeocene/Eocene warm period, Nature, 439, 60-63, 2006.

Pagani, M., Caldeira, K., Archer, D., and Zachos, J. C.: An ancient carbon mystery, Science, 314, 1556-1557, 2006.

Paytan, A., Kastner, M., and Chavez, F. P.: Glacial to Interglacial Fluctuations in Productivity in the Equatorial Pacific as Indicated by Marine Barite, Science, 274, 1355-1357, 1996.

Paytan, A., Averyt, K., Faul, K., Gray, E., and Thomas, E.: Barite accumulation, ocean productivity, and $\mathrm{Sr} / \mathrm{Ba}$ in barite across the 
Paleocene-Eocene Thermal Maximum, Geology, 35, 1139-1142, 2007.

Paytan, A. and Griffith, E. M.: Marine barite: Recorder of variations in ocean export productivity, Deep Sea Res. Pt. II, 54, 687-705, 2007.

Rea, D. K. and Leinen, M.: Asian aridity and the zonal westerlies: Late Pleistocene and Holocene record of eolian deposition in the northwest Pacific Ocean, Palaeogeogr. Palaeocl., 66, 1-8, 1988.

Robert, C. and Kennett, J. P.: Antarctic subtropical humid episode at the Paleocene-Eocene boundary- clay-mineral evidence, Geology, 22, 211-214, 1994.

Röhl, U., Bralower, T. J., Norris, R. D., and Wefer, G.: New chronology for the late Paleocene thermal maximum and its environmental implications, Geology, 28, 927-930, 2000.

Röhl, U., Westerhold, T., Bralower, T. J., and Zachos, J. C.: On the duration of the Paleocene-Eocene thermal maximum (PETM), Geochem. Geophy. Geosy., 8, Q12002, doi:10.1029/2007GC001784, 2007.

Schmitz, B., Charisi, S. D., Thompson, E. I., and Speijer, R. P.: Barium, $\mathrm{SiO}_{2}$ (excess), and $\mathrm{P}_{2} \mathrm{O}_{5}$ as proxies of biological productivity in the Middle East during the Palaeocene and the latest Palaeocene benthic extinction event, Terra Nova, 9, 95-99, 1997.

Schouten, S., Woltering, M., Rijpstra, W. I. C., Sluijs, A., Brinkhuis, H., and Sinninghe Damste', J. S.: The Paleocene-Eocene carbon isotope excursion in higher plant organic matter: Differential fractionation of angiosperms and conifers in the Arctic, Earth Planet. Sc. Lett., 258, 581-592, 2007.

Sluijs, A., Schouten, S., Pagani, M., Woltering, M., Brinkhuis, H., Damste, J. S. S., Dickens, G. R., Huber, M., Reichart, G. J., Stein, R., Matthiessen, J., Lourens, L. J., Pedentchouk, N., Backman, J., Moran, K., and Expedition, S.: Subtropical arctic ocean temperatures during the Palaeocene/Eocene thermal maximum, Nature, 441, 610-613, 2006.

Sluijs, A., Brinkhuis, H., Schouten, S., Bohaty, S. M., John, C. M., Zachos, J. C., Reichart, G. J., Damste, J. S. S., Crouch, E. M., and Dickens, G. R.: Environmental precursors to rapid light carbon injection at the Palaeocene/Eocene boundary, Nature, 450, 12181221, 2007.

Sluijs, A., Bowen, G. J., Brinkhuis, H., Lourens, L. J., and Thomas, E.: The Paleocene-Eocene Thermal Maximum super greenhouse: biotic and geochemical signatures, age models and mechanisms of global change, in: Deep-Time Perspectives on Climate Change: Marrying the Signal from Computer Models and Biological Proxies, edited by: Williams, M., Haywood, A. M., Gregory, F. J., and Schmidt, D. N., Geol. Soc. Spec. Publ., London, 323-349, 2007.

Stoll, H. M. and Bains, S.: Coccolith $\mathrm{Sr} / \mathrm{Ca}$ records of productivity during the Paleocene-Eocene thermal maximum from the Weddell Sea, Paleoceanography, 18(2), 1049, doi:10.1029/2002PA000875, 2003.
Stoll, H. M., Shimizu, N., Archer, D., and Ziveri, P.: Coccolithophore productivity response to greenhouse event of the Paleocene-Eocene Thermal Maximum, Earth Planet. Sc. Lett., 258, 192-206, 2007.

Svensen, H., Planke, S., Malthe-Sorenssen, A., Jamtveit, B., Myklebust, R., Eidem, T. R., and Rey, S. S.: Release of methane from a volcanic basin as a mechanism for initial Eocene global warming, Nature, 429, 542-545, 2004.

Thomas, E. and Shackleton, N. J.: The Paleocene-Eocene benthic foraminiferal extinction and stable isotope anomalies, Geol. Soc. Sp., 101, 401-441, 1996.

Tripati, A. and Elderfield, H.: Deep-sea temperature and circulation changes at the Paleocene-Eocene thermal maximum, Science, 308, 1894-1898, 2005.

Tripati, A. K. and Elderfield, H.: Abrupt hydrographic changes in the equatorial Pacific and subtropical Atlantic from foraminiferal $\mathrm{Mg} / \mathrm{Ca}$ indicate greenhouse origin for the thermal maximum at the Paleocene-Eocene Boundary, Geochem. Geophy. Geosy., 5, Q02006, doi:10.1029/2003GC000631, 2004.

Westerhold, T., Röhl, U., Laskar, J., Raffi, I., Bowles, J., Lourens, L. J., and Zachos, J. C.: On the duration of magnetochrons $\mathrm{C} 24 \mathrm{r}$ and $\mathrm{C} 25 \mathrm{n}$ and the timing of early Eocene global warming events: Implications from the Ocean Drilling Program Leg 208 Walvis Ridge depth transect, Paleoceanography, 22, PA2201, doi:10.1029/2006PA001322, 2007.

Westerhold, T., Röhl, U., Raffi, I., Fornaciari, E., Monechi, S., Reale, V., Bowles, J., and Evans, H. F.: Astronomical calibration of the Paleocene time, Palaeogeogr. Palaeocl., 257, 377-403, 2008.

Winckler, G., Anderson, R. F., Stute, M., and Schlosser, P.: Does interplanetary dust control 100 kyr glacial cycles?, Quaternary Sci. Rev., 23, 1873-1878, 2004.

Winckler, G., Anderson, R. F., and Schlosser, P.: Equatorial Pacific productivity and dust flux during the midPleistocene climate transition, Paleoceanography, 20, PA4025, doi:10.1029/2005PA001177, 2005.

Zachos, J., Pagani, M., Sloan, L., Thomas, E., Billups, K.: Trends, rhythms, and aberrations in global climate 65 Ma to present, Science, 292, 686-693, 2001.

Zachos, J. C., Wara, M. W., Bohaty, S., Delaney, M. L., Petrizzo, M. R., Brill, A., Bralower, T. J., and Premoli-Silva, I.: A transient rise in tropical sea surface temperature during the PaleoceneEocene Thermal Maximum, Science, 302, 1551-1554, 2003.

Zachos, J. C., Röhl, U., Schellenberg, S. A., Sluijs, A., Hodell, D. A., Kelly, D. C., Thomas, E., Nicolo, M., Raffi, I., Lourens, L. J., McCarren, H., and Kroon, D.: Rapid acidification of the ocean during the Paleocene-Eocene thermal maximum, Science, 308, 1611-1615, 2005. 